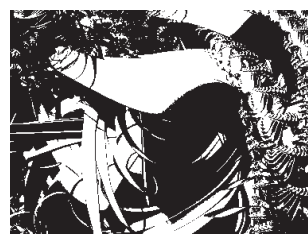

\title{
RODITELJSKO PONAŠANJE ZAPOSLENIH RODITELJA: POVEZANOST S OBJEKTIVNIM OBILJEŽJIMA POSLA I SUBJEKTIVNIM DOŽIVLJAJEM ODNOSA RODITELJSKE I RADNE ULOGE
}

Mateja SOČO

Diečii vrtić Ciciban, Velika Gorica

Gordana KERESTEŠ

Filozofski fakultet, Zagreb

UDK: 159.923-055.52-057.1

Izvorni znanstveni rad

Primlieno: 10. 1. 2010.

Rad se temelii na diplomskom radu prve autorice izrađenom pod mentorstvom druge autorice i dijelom je proizašao iz znanstvenoga projekta Ličnost roditelia $i$ roditelistvo tijekom tranzicije dieteta u adolescenciju, koji se provodi uz potporu MZOŠ RH (130-

-1301683-1400).
Polazeći od modela determinanti roditeljskoga ponašanja (Belsky, 1984.), u ovom radu ispitana je povezanost roditeliskoga ponašanja zaposlenih roditelja s objektivnim obiliežjima posla i roditeljevim subjektivnim doživljajem odnosa između roditeliske i radne uloge. $U$ istraživanju su sudjelovala 162 zaposlena oca i 380 zaposlenih majki, koji su imali diecu od 3 do 16 godina. Podaci su prikupljeni online upitnicima primijenjenim na internetu. Rezultati su pokazali da su karakteristike posla u nešto većoj mieri povezane s roditeljskim ponašanjem očeva nego majki, osobito kad se razmatra negativno roditelistvo. U roditelia obaju spolova subjektivan doživliaj posla jače je povezan s roditeliskim ponašanjem od objektivnih obiliežja posla. Najznačajniji predikłori roditeliskoga ponašanja roditelja obaju spolova bili su doživliaj ometanja radne uloge roditeljskom i procjena važnosti roditeljske uloge. Majčino roditelistvo bilo je značajno povezano i s procjenom važnosti radne uloge. Raspravljene su teorijske i praktične implikacije dobivenih nalaza i dane smjernice za buduća istraživanja.

Ključne riječi: majke, očevi, posao, sukob roditeljske i radne uloge, roditeljsko ponašanje

- Mateja Sočo, Dječji vrtić Ciciban, Vladimira Vidrića 2,

10410 Velika Gorica, Hrvatska.
E-mail: mateja.soco@gmail.com 
Roditeljska i radna uloga središnje su uloge odraslih osoba u raznim kulturama širom svijeta. Unatoč razmjerno visokoj stopi nezaposlenosti, u Hrvatskoj, kao i drugim industrijaliziranim zemljama, većina roditelja maloljetne djece zaposlena je izvan svojega doma. Brz tehnološki razvoj i društvene promjene u novije su vrijeme povećali zahtjeve svake od tih uloga, a njihovo usklađivanje učinili vrlo složenim (Gottfried i sur., 2002.; Čudina-Obradović i Obradović, 2000., 2001.).

Iako su u zadnjih nekoliko desetljeća provedena brojna istraživanja interakcije posao - obitelj (pregledi se mogu naći u Čudina-Obradović i Obradović, 2000., 2001.), njihovi rezultati ne govore mnogo o roditeljskom funkcioniranju zaposlenih roditelja, jer u nedovoljnoj mjeri razlučuju obiteljske uloge. U većini ranijih istraživanja primijenjene su globalne, nespecifične mjere odnosa obitelj - posao, pa najčešće nije jasno pridonosi li interakciji posla i obitelji i doživljaju njihove (ne) usklađenosti roditeljska uloga, uloga supružnika ili uloga djeteta ostarjeloga roditelja (Mallard i Lance, 1998.). Za potpunije razumijevanje odnosa posao - obitelj potrebno je zasebno razmotriti različite obiteljske uloge zaposlenika. $U$ ovom radu bavimo se roditeljskom ulogom. Teorijski okvir kojim se rukovodimo jest procesni model determinanti roditeljstva (Belsky, 1984.), prema kojem je radno mjesto roditelja važna kontekstualna determinanta roditeljskoga ponašanja i važan izvor stresa ili/i podrške roditeljima u roditeljskom funkcioniranju.

Ranija istraživanja roditeljskoga funkcioniranja zaposlenih roditelja većinom su bila usmjerena na majke i potaknuta, $u$ najvećoj mjeri, porastom udjela žena u svijetu rada, do kojeg je došlo u drugoj polovici 20. stoljeća. Temeljna pretpostavka prve generacije istraživanja majčine zaposlenosti bila je da majčina zaposlenost negativno utječe na djetetov razvoj. Međutim, empirijski nalazi uglavnom nisu potvrdili tu pretpostavku, nego su pokazali kako učinak majčine zaposlenosti ovisi o drugim činiteljima, ponajprije o majčinu roditeljskom ponašanju i odgojnom stilu. U suvremenoj literaturi ističe se kako zaposlenost roditelja nema izravan nego posredan učinak na djetetov razvoj, djelujući na roditeljsko ponašanje (Gottfried i sur., 2002.; Holden, 2010.). No istraživanja kojima se ispituje povezanost posla i roditeljskoga ponašanja novijeg su datuma i vrlo se malo zna o karakteristikama posla koje su povezane s roditeljskim ponašanjem.

U ovom radu ispitujemo kako su neka objektivna obilježja posla (duljina radnoga vremena, zahtjevi koje posao stavlja pred pojedinca, stupanj autonomije u poslu i fleksibilnost posla) i roditeljev subjektivni doživljaj odnosa posla i roditeljstva (važnost posla i roditeljstva za pojedinca te procjena su- 
DRUŠ. ISTRAŽ. ZAGREB GOD. 20 (2011), BR. 3 (113),

STR. 647-669

SOČO, M., KERESTEŠ, G.: RODITELJSKO... koba tih dviju uloga, odnosno ometanja roditeljske uloge radnom i radne roditeljskom) povezani s roditeljskim ponašanjem. Malobrojna ranija istraživanja pokazala su kako je jedno od najvažnijih obilježja posla za roditeljstvo stupanj autonomije. Roditelji čiji je posao kompleksniji i omogućuje im veću autonomiju stvaraju pozitivnije obiteljsko ozračje te pružaju djeci više emocionalne topline i kognitivne stimulacije (Menaghan i Parcel, 1991.). Veća autonomija u poslu povezana je i s manje restriktivnom kontrolom majki (Mason i sur., 1994.) te s očevim induktivnim odgojnim postupcima i izbjegavanjem strogih kazni (Whitbeck i sur., 1997.).

Od ostalih obilježja posla obuhvaćenih ovim radom, ranija su istraživanja ispitivala duljinu radnoga vremena, zahtjevnost posla te konflikte poslovne i obiteljske uloge. Pokazalo se da majke koje na poslu provode više sati manje nadziru djetetovo ponašanje nakon škole (Muller, 1995.), a u dane koji su im na poslu naporniji manje razgovaraju s djecom i pokazuju im manje emocija (Repetti i Wood, 1997.). Očevi i majke adolescenata koji rade više sati na tjedan, osjećaju veći konflikt obiteljske i poslovne uloge i skloniji su svađama s djecom (Crouter i sur., 1999.). Očevi koji uz dugačko radno vrijeme izvještavaju i o većim zahtjevima posla imaju lošiji odnos s adolescentima (Crouter i sur., 2001.). Stewart i Barling (1996.) nisu pronašli povezanost između zahtjeva posla i očeva roditeljskoga ponašanja, ali je doživljaj jačeg ometanja obiteljskoga života poslom bio povezan s više kažnjavanja i većim odbacivanjem djeteta.

Fleksibilnost posla te važnost poslovne i roditeljske uloge prema našim spoznajama do sada nisu izravno povezivani $\mathrm{s}$ roditeljskim ponašanjem, ali se na temelju nalaza o njihovoj povezanosti sa psihičkim zdravljem i dobrobiti zaposlenika (Gronlund, 2007.; Hughes i Parkes, 2007.; Jelušić i Maslić Seršić, 2005.; Reitzes i Mutran, 2002.; Šverko i sur., 2002.; Thompson i Prottas, 2006.) te teorijskih razmatranja njihove relevantnosti za roditeljsko funkcioniranje (Belsky, 1984.; Holden, 2010.; Martin i Colbert, 1997.) može pretpostaviti da značajno utječu na roditeljsko ponašanje. Ukratko, na temelju ranijih istraživanja i teoretiziranja pretpostavili smo da će kraće radno vrijeme, manji zahtjevi posla, veća autonomija i fleksibilnost posla, manja važnost posla, veća važnost roditeljstva, manje ometanje roditeljske uloge radnom i radne roditeljskom biti povezani s konstruktivnijim i pozitivnijim roditeljskim ponašanjima.

Spol roditelja važna je odrednica roditeljskoga ponašanja. Roditeljska uloga majki i očeva razlikuje se čak i u društvima u kojima je ostvaren najviši stupanj ravnopravnosti muškaraca i žena, pri čemu je odgoj djece u većoj mjeri majčina odgovornost nego očeva (Gronlund, 2007.; Parke, 2002.; Russell i Rus- 
DRUŠ. ISTRAŽ. ZAGREB GOD. 20 (2011) BR. $3(113)$

STR. 647-669

SOČO, M., KERESTEŠ, G.: RODITELJSKO... sell, 1987.). U tradicionalnijim kulturama, poput naše, razlike u roditeljskim odgovornostima, ulogama i ponašanjima majki i očeva još su izraženije. U ovom radu ispitujemo moguću različitu povezanost posla i roditeljskoga ponašanja zaposlenih očeva i majki. Premda je poznato da neke aspekte interakcije posao - obitelj žene i muškarci doživljavaju različito - primjerice, zaposlene žene provode više vremena u obavljanju obiteljskih poslova nego zaposleni muškarci (Šverko i sur., 2002.; Voydanoff, 2002.) i procjenjuju da im posao u većoj mjeri ometa obiteljsku (Šverko i sur., 2002.; Wiersma i van den Berg, 1991.) i roditeljsku ulogu (Mallard i Lance, 1998.) - mogući učinak tih razlika na roditeljsko ponašanje nije poznat. Pitanje je li posao u većoj mjeri povezan s majčinim ili očevim roditeljskim ponašanjem te je li priroda povezanosti između obilježja posla i roditeljskoga ponašanja slična ili različita za zaposlene majke i očeve ostaje otvoreno.

Roditeljsko ponašanje najčešće se opisuje trima bipolarnim dimenzijama - emocionalnom toplinom / hladnoćom prema djetetu, čvrstom / slabom kontrolom djetetova ponašanja i psihološkom kontrolom / autonomijom - te iz njih izvedenim roditeljskim stilovima: autoritativnom, autoritarnom, permisivnom i zanemarujućem (Holden, 2010.; Maccoby, 2000.). No neki autori roditeljstvu prilaze razlikujući pozitivne (ili konstruktivne, učinkovite) od negativnih (destruktivnih ili neučinkovitih) aspekata roditeljskoga ponašanja (Eisenberg i sur., 2005.; Keresteš, 2006.; Kuterovac Jagodić i sur., 2006.; McKee i sur., 2007.). U pozitivne aspekte uvrštavaju emocionalnu toplinu, nadzor, discipliniranje utemeljeno na postavljanju granica, induktivno rezoniranje (objašnjavanje pravila i važnosti njihova pridržavanja) i dosljednost, a u negativne ljutnju, neprijateljstvo i odbacivanje djeteta te strogo discipliniranje, koje uključuje prisilu te verbalno i tjelesno kažnjavanje. U ovom radu polazimo od takve konceptualizacije te ispitujemo pozitivno i negativno roditeljsko ponašanje, kao i roditeljsku popustljivost kao zaseban aspekt roditeljstva, nepovezan s pozitivnim i negativnim roditeljstvom.

Ukratko, ovim radom želimo odgovoriti na dva istraživačka pitanja: (1) koliki dio varijance roditeljskoga ponašanja zaposlenih očeva i majki (pozitivnoga roditeljstva, negativnoga roditeljstva i popustljivosti) objašnjavaju ispitivana objektivna obilježja posla i subjektivni doživljaj odnosa poslovne i roditeljske uloge te je li posao važnija determinanta majčina ili očeva roditeljskog ponašanja, (2) koji su od ispitivanih objektivnih i subjektivnih aspekata radnoga konteksta najviše povezani s roditeljskim ponašanjem te jesu li povezanosti slične za očeve i majke. Iako je temeljni cilj rada razmotriti povezanosti između roditeljskoga ponašanja i obilježja posla kao kon- 
DRUŠ. ISTRAŽ. ZAGREB GOD. 20 (2011), BR. 3 (113)

STR. 647-669

SOČO, M., KERESTEŠ, G.: RODITELJSKO... tekstualne determinante toga ponašanja, uzeli smo u obzir i osnovne demografske karakteristike roditelja (dob, obrazovanje i broj djece) i ciljanoga djeteta (dob i spol), koje su, prema modelu determinanti roditeljskoga ponašanja, također povezane s individualnim razlikama u roditeljstvu (Belsky, 1984.).

\section{METODA}

\section{Postupak i sudionici}

Istraživanje je provedeno preko interneta. Konstruirana je online verzija baterije upitnika, koja je bila postavljena na web-portalu MojPosao od početka travnja do početka svibnja 2009. godine. Posjetitelji web-portala pozivani su na sudjelovanje $u$ istraživanju putem grafičkih oglasa (bannera). Uvjet za sudjelovanje bio je da su zaposleni i imaju dijete od 3 do 16 godina. Uputom su objašnjeni svrha i postupak istraživanja te načini na koje su riješena etička pitanja (anonimnost i tajnost podataka). Objašnjeno je kako roditelji s više djece trebaju davati odgovore o najstarijem djetetu, ali ne starijem od $16 \mathrm{ni}$ mlađem od 3 godine. Za ispunjavanje upitnika trebalo je dvadesetak minuta.

Istraživanju je pristupilo 740 osoba. Od toga ih je 15 bilo nezaposleno ili u mirovini, 55 ih nije imalo djece, 104 je imalo djecu mlađu od 3, a 23 stariju od 16 godina, a jedan upitnik nije bio valjan. Stoga se uzorak na kojem su provedene analize sastoji od 542 zaposlena roditelja - 380 majki i 162 oca. Struktura uzorka prikazana je u Tablici 1. Kako se vidi iz tablice, riječ je o prigodnom uzorku izrazito pristranom prema višem socioekonomskom statusu, što je očekivano i uobičajeno kod internetskih istraživanja (npr. Šverko i sur., 2002.), ali treba uzeti u obzir u interpretaciji rezultata. Približno dvije trećine roditelja imaju fakultetsko i više (poslijediplomsko) obrazovanje, gotovo polovica očeva i četvrtina majki ima mjesečnu plaću veću od 8000 kuna, $28 \%$ očeva i $18 \%$ majki radi na rukovodećim mjestima. Gotovo svi očevi te $89 \%$ majki žive s partnerom i više od $90 \%$ partnera je zaposleno. Većina roditelja (više od 50\%) ima dvoje djece. Prosječna dob roditelja je 37 godina. Ciljana djeca (u odnosu na koju su roditelji procjenjivali roditeljsko ponašanje) $u$ podjednakom su broju dječaci i djevojčice, približno polovica ih je predškolske dobi (od 3 do 6 godina), a po četvrtina rane školske (od 7 do 11 godina) $\mathrm{i}$ adolescentne (od 12 do 16 godina) dobi. Većina ciljane djece jesu prvorođenci, što je očekivano s obzirom na uputu roditeljima da odgovaraju o najstarijem djetetu u dobi od 3 do 16 godina. Desetina djece kasnijega redoslijeda rođenja najvjerojatnije ima braću / sestre starije od 16 godina. 


\begin{tabular}{|c|c|c|c|c|c|}
\hline & \multicolumn{2}{|c|}{$\begin{array}{r}\text { Očevi } \\
(\mathrm{N}=162)\end{array}$} & \multicolumn{2}{|c|}{$\begin{array}{c}\text { Majke } \\
(\mathrm{N}=380)\end{array}$} & \multirow[b]{2}{*}{ Razlika } \\
\hline & $\mathrm{N}$ & $\%$ & $\mathrm{~N}$ & $\%$ & \\
\hline \multicolumn{6}{|l|}{ Dob } \\
\hline 23 - 30 godina & 10 & 6,2 & 41 & 10,8 & \multirow{4}{*}{$\begin{array}{l}\mathrm{MO}=38,09 ; \mathrm{MM}=36,69 \\
\mathrm{SDO}=5,734 ; \mathrm{SDM}=5,231 \\
\mathrm{t}(540)=2,766, \mathrm{p}=0,006^{* *}\end{array}$} \\
\hline 31 - 40 godina & 107 & 66 & 250 & 65,8 & \\
\hline $41-50$ godina & 39 & 21,4 & 87 & 22,9 & \\
\hline $51-55$ godina & 6 & 3,7 & 2 & 0,5 & \\
\hline \multicolumn{6}{|l|}{ Obrazovanje } \\
\hline Srednja škola i manje & 51 & 31,5 & 126 & 33,2 & \multirow[t]{3}{*}{$\chi^{2}(2)=1,496, p=0,473$} \\
\hline Viša škola i fakultet & 88 & 54,3 & 214 & 56,3 & \\
\hline Poslijediplomsko obrazovanje & 23 & 14,2 & 40 & 10,5 & \\
\hline \multicolumn{6}{|l|}{ Kategorija posla } \\
\hline Zaposlenik & 106 & 65,4 & 285 & 75 & \multirow[t]{3}{*}{$\chi^{2}(2)=6,788, p=0,034^{*}$} \\
\hline Rukovoditelj & 45 & 27,8 & 68 & 17,9 & \\
\hline Ostalo & 11 & 6,8 & 27 & 7,1 & \\
\hline \multicolumn{6}{|l|}{ Prosječna neto plaća } \\
\hline $2000-4000 \mathrm{kn}$ & 11 & 7,2 & 67 & 18,9 & \multirow[t]{3}{*}{$\chi^{2}(2)=33,992, p=0,000^{* * *}$} \\
\hline $4001-8000$ kn & 66 & 43,4 & 201 & 56,8 & \\
\hline Viša od 8000 kn & 75 & 49,3 & 86 & 24,3 & \\
\hline \multicolumn{6}{|l|}{ Bračni status } \\
\hline S partnerom & 155 & 95,7 & 338 & 88,9 & \multirow[t]{2}{*}{$\chi^{2}(1)=6,259, p=0,012^{*}$} \\
\hline Bez partnera & 7 & 4,3 & 42 & 11,1 & \\
\hline \multicolumn{6}{|l|}{ Radni status partnera } \\
\hline Zaposlen & 144 & 90,6 & 317 & 91,4 & \multirow[t]{2}{*}{$\chi^{2}(1)=0,084, p=0,772$} \\
\hline Nezaposlen ili u mirovini & 15 & 9,4 & 30 & 8,6 & \\
\hline \multicolumn{6}{|l|}{ Broj djece } \\
\hline 1 & 49 & 30,2 & 138 & 36,3 & \multirow[t]{3}{*}{$\chi^{2}(2)=1,852, p=0,396$} \\
\hline 2 & 94 & 58 & 201 & 52,9 & \\
\hline 3 i više & 19 & 11,7 & 41 & 10,8 & \\
\hline \multicolumn{6}{|l|}{ Redoslijed rođenja ciljanoga djeteta } \\
\hline Prvorođeno & 137 & 84,6 & 327 & 86,1 & \multirow[t]{4}{*}{$\chi^{2}(3)=0,870, p=0,833$} \\
\hline Drugorođeno & 19 & 11,7 & 36 & 9,5 & \\
\hline Trećerođeno & 5 & 3,1 & 13 & 3,4 & \\
\hline Četvrtorođeno i petorođeno & 1 & 0,6 & 4 & 1,1 & \\
\hline \multicolumn{6}{|l|}{ Dob ciljanoga djeteta } \\
\hline $3-6$ godina & 85 & 52,5 & 170 & 44,7 & \multirow{3}{*}{$\begin{array}{l}\mathrm{MO}=7,43 ; \mathrm{MM}=8,18 \\
\mathrm{SDO}=3,649 ; \mathrm{SDM}=4,046 \\
\text { at }(334,88)=-2,123, \mathrm{p}=0,034^{*}\end{array}$} \\
\hline 7 - 11 godina & 41 & 25,3 & 95 & 25 & \\
\hline $12-16$ godina & 36 & 22,2 & 115 & 30,3 & \\
\hline \multicolumn{6}{|l|}{ Spol ciljanoga djeteta } \\
\hline Muški & 88 & 54,3 & 203 & 53,4 & \multirow[t]{2}{*}{$\chi^{2}(1)=0,037, p=0,847$} \\
\hline Ženski & 74 & 45,7 & 177 & 46,6 & \\
\hline
\end{tabular}

Napomena: akorekcija zbog nehomogene varijance (statistički značajnoga Leveneova testa) ${ }^{*} \mathrm{p}<0,05,{ }^{* *} \mathrm{p}<0,01,{ }^{* * *} \mathrm{p}<0,001$

(1) TABLICA 1

Demografska obiliežja uzorka i značajnost razlika između majki i očeva
Testiranjem značajnosti razlika između majki i očeva utvrđeno je da su majke, u odnosu na očeve, oko godinu dana mlađe, da su izvještavale o približno godinu dana mlađem djetetu, da ih je manje bilo na rukovodećim položajima, da su 
imale manju plaću i da ih je više bilo u ulozi samohranoga roditelja (Tablica 1 ).

\section{Varijable i instrumenti}

Sociodemografske varijable i radno vrijeme

Prvi dio baterije upitnika sastojao se od pitanja o sociodemografskim obilježjima i tjednom radnom vremenu u satima.

Obilježja posla - zahtjevnost, fleksibilnost i autonomija

Drugi dio baterije upitnika sastojao se od skala za ispitivanje objektivnih obilježja posla: Skale zahtjeva na poslu, Skale fleksibilnosti na poslu i Skale autonomije na poslu.

Skala zahtjeva na poslu preuzeta je iz istraživanja Jelušić i Maslić Seršić (2005.). Obuhvaća pet čestica koje opisuju zahtjeve posla: rad u smjenama, vikendom i navečer, poslovna putovanja te "nošenje" posla kući. Roditelji procjenjuju u kolikoj se mjeri opisani zahtjevi odnose na njih (od 1=nikada do $4=$ uvijek). Ukupan rezultat formiran je kao prosjek rezultata na svim česticama. Veći rezultat znači više zahtjeva na poslu. Pouzdanosti dobivene $u$ ovom istraživanju razmjerno su niske (Cronbachov alfa za očeve iznosi 0,55 , a za majke 0,65 ), što treba uzeti u obzir u interpretaciji rezultata.

Skala fleksibilnosti na poslu sastoji se od šest pitanja koja ispituju organizacijske mjere povoljne za obiteljski život zaposlenika. Skala je preuzeta iz istraživanja Jelušić i Maslić Seršić (2005.). Pitanja se odnose na klizno radno vrijeme, plaćeno bolovanje zbog bolesti djeteta, plaćen rodiljni dopust, mogućnost prelaska s punoga radnog vremena na skraćeno, mogućnost obavljanja dijela radnih zadataka od kuće i mogućnost izostajanja s posla zbog hitnih roditeljskih dužnosti. Na pitanja se odgovara sa "ne" ako mjera fleksibilnosti nije dostupna (čemu je pridijeljena vrijednost 0 ) ili sa "da" ako je dostupna (brojčana vrijednost 1). Ukupan raspon rezultata kreće se od 0 do 6 . Veći rezultat znači veću fleksibilnost na poslu. Pouzdanosti dobivene $u$ ovom istraživanju razmjerno su niske (Cronbachov alfa za očeve iznosi 0,62, a za majke 0,57 ), što treba uzeti $\mathrm{u}$ obzir $\mathrm{u}$ interpretaciji rezultata.

Skala autonomije na poslu preuzeta je iz istraživanja Costiganove i sur. (2003.) te je za potrebe ovog istraživanja prevedena na hrvatski jezik i prilagođena. Sastoji se od pet čestica koje ispituju stupanj u kojem posao pruža priliku za rast i neovisnost (npr. "Moj posao omogućuje mi da mnoge odluke donesem samostalno"). Roditelji procjenjuju koliko su pojedine tvrdnje točne za njih $(1=$ uopće nije točno, $4=$ potpuno točno). Ukupan rezultat formira se kao prosjek rezultata u svim česticama. Veća vrijednost označuje veću autonomiju na poslu. Cronbachov alfa u ovom istraživanju iznosi 0,86 za očeve i 0,82 za majke. 
DRUŠ. ISTRAŽ. ZAGREB GOD. 20 (2011) BR. $3(113)$

STR. 647-669

SOČO, M., KERESTEŠ, G. RODITELJSKO...
Subjektivni doživljaj odnosa roditeljske i radne uloge - važnost i sukob uloga

Treći dio baterije obuhvaćao je četiri varijable koje opisuju subjektivni doživljaj posla, odnosno odnosa između roditeljske i radne uloge: važnost radne uloge, važnost roditeljske uloge, ometanje roditeljske uloge radnom te ometanje radne uloge roditeljskom.

Važnost radne i roditeljske uloge ispitana je po jednom česticom u kojoj su roditelji procijenili koliko im je svaka od tih uloga važna (od $1=$ nimalo važna do $10=$ vrlo važna).

Upitnik sukoba radne i roditeljske uloge (Mallard i Lance, 1998.) preveden je i prilagođen potrebama ovog istraživanja. Originalni upitnik sastoji se od 40 čestica raspoređenih u tri skale. Jedna skala mjeri koliko roditeljska uloga ometa radnu, druga koliko radna uloga ometa roditeljsku, a treća opći sukob dviju uloga. U ovom istraživanju primijenili smo samo prve dvije skale, jer nas je više zanimao odnos dviju uloga nego općenit sukob među njima. Osim toga, pitanja iz treće skale sadržajno se u velikoj mjeri preklapaju s pitanjima iz prve dvije skale, pa smo željeli izbjeći tu redundantnost. Skala sukoba radne uloge s roditeljskom ulogom ima 17 čestica (primjer: "Moj posao otežava mi da budem roditelj kakav bih htio/htjela biti"). Pouzdanost (Cronbachov alfa) u ovom istraživanju iznosi 0,93 za očeve i 0,92 za majke. Skala sukoba roditeljske uloge s radnom ulogom obuhvaća 15 čestica (primjer: "Na poslu provodim neproduktivno vrijeme jer sam zabrinut/a za dijete/djecu"). U ovom istraživanju Cronbachov je alfa 0,88 za očeve i 0,89 za majke. Roditelji u svim česticama procjenjuju koliko je pojedina tvrdnja točna za njih ( $1=$ uopće nije točno, $4=$ potpuno točno). Ukupan rezultat formira se kao prosjek bodova u svim česticama odgovarajuće skale.

Kako su u ovom radu dvije skale prvi put primijenjene $\mathrm{u}$ našoj zemlji, faktorskom analizom metodom glavnih komponenata uz oblimin rotaciju provjerili smo njihovu faktorsku strukturu. Dobiveno je rješenje od šest faktora, ali su veličine karakterističnih korijena i scree test sugerirali dva dominantna faktora $\left(\mathrm{KKF}_{\mathrm{F} 1}=10,550, \mathrm{KK}_{\mathrm{F} 2}=4,330\right)$ koji objašnjavaju 46,5\% varijance rezultata i odgovaraju očekivanim faktorima ometanja radne uloge roditeljskom (F1) i roditeljske radnom (F2). Uz iznim$\mathrm{ku}$ četiriju čestica koje su podjednako saturirane s oba faktora ili su više saturirane neočekivanim nego očekivanim faktorom, ostale čestice imaju očekivane saturacije, što govori o faktorskoj valjanosti skala. Korelacija između dva faktora iznosi 0,339. Faktorska struktura može se na zahtjev dobiti od prve autorice.

Roditeljsko ponašanje - pozitivno roditeljstvo, negativno roditeljstvo i popustljivost

Posljednji, četvrti, dio baterije upitnika sadržavao je Upitnik roditeljskoga ponašanja URP-29 (Keresteš i sur., 2008.), sastavljen od 29 čestica koje opisuju roditeljska ponašanja. Roditelji pro- 
DRUŠ. ISTRAŽ. ZAGREB GOD. 20 (2011), BR. 3 (113)

STR. $647-669$

SOČO, M., KERESTEŠ, G.: RODITELJSKO... cjenjuju koliko je svaka tvrdnja točna za njih $(1=$ uopće nije točno za mene, 4 = potpuno točno). Upitnik obuhvaća sedam aspekata roditeljskoga ponašanja, odnosno sedam skala: prihvaćanje (roditeljevo pokazivanje ljubavi, prihvaćanja, topline i bliskosti), autonomiju (roditeljevo poštivanje djeteta kao osobe), psihološku kontrolu (kontroliranje djeteta ispitivanjem, nametanjem i "miješanjem" $\mathrm{u}$ djetetov život), nadzor (roditeljeva upoznatost s djetetovim aktivnostima i obvezama), popustljivost (udovoljavanje djetetovim zahtjevima i popuštanje), pozitivnu disciplinu (korištenje pozitivnih, podražavajućih i argumentiranih postupaka discipliniranja) i negativnu disciplinu (oštre, hladne i odbacujuće metode discipliniranja). Premda je sedam skala pokazalo zadovoljavajuću unutrašnju konzistenciju (Cronbachove alfe u ovom istraživanju kretale su se od 0,57 do 0,76), odlučili smo formirati tri globalna rezultata, koja, na temelju faktorskih analiza rezultata na skalama provedenim u ovom i u ranijem istraživanju, primjena URP-29 također omogućuje: pozitivno roditeljstvo (uključuje skale prihvaćanja, autonomije, nadzora i pozitivne discipline i obuhvaća 17 čestica), negativno roditeljstvo (skale psihološke kontrole i negativne discipline, ukupno 9 čestica) i popustljivost kao zaseban rezultat, odnosno faktor (obuhvaća 3 čestice). Rezultati na ovim globalnim dimenzijama roditeljskoga ponašanja formiraju se kao prosjek rezultata na pripadajućim česticama. Koeficijenti pouzdanosti (Cronbachov alfa) u ovom istraživanju iznose 0,85 za pozitivno roditeljstvo obaju roditelja, 0,74 za očevo, a 0,73 za majčino negativno roditeljstvo te 0,68 za očevu i 0,72 za majčinu popustljivost.

\section{REZULTATI}

\section{Preliminarne analize}

Prije glavnih obradbi, uvidom u grafički oblik distribucija i Kolmogorov-Smirnovljevim testom provjerili smo normalitet distribucija varijabli. Kolmogorov-Smirnov test bio je značajan za većinu varijabli, osobito u uzorku majki, ali je to najvećim dijelom posljedica njegove izvanredne osjetljivosti na veličinu uzorka (Gamst i sur., 2008.), odnosno razmjerno velikih uzoraka majki i očeva u našem istraživanju. Kako su grafički prikazi pokazali da sve varijable imaju oblik normalne krivulje, podaci su obrađeni parametrijskim postupcima.

Tablica 2 prikazuje deskriptivne pokazatelje glavnih varijabli $\mathrm{u}$ istraživanju te rezultate testiranja značajnosti razlika između majki i očeva. Razlike su testirane t-testom, uz prethodnu provjeru homogenosti varijanci Leveneovim testom. Za zahtjeve i fleksibilnost posla, važnost roditeljske uloge te pozitivno roditeljstvo Leveneov je test značajan, odnosno pokazuje da se varijance razlikuju, pa su prikazane korigirane vrijednosti t-testa. Kako smo proveli razmjerno velik broj t-te- 
DRUŠ. ISTRAŽ. ZAGREB GOD. 20 (2011) BR. $3(113)$

STR. 647-669

SOČO, M., KERESTEŠ, G.: RODITELJSKO..

(1) TABLICA 2

Deskriptivni pokazatelii glavnih varijabli u istraživanju te razlike između majki i očeva stova, zbog čega je povećana mogućnost pojave pogreške tipa I, pri određivanju razine značajnosti koristili smo se Bonferronijevom korekcijom. Uz Bonferronijevu korekciju, odnosno razinu statističke značajnosti 0,005 , očevi i majke razlikuju se samo $u$ tjednom radnom vremenu i pozitivnom roditeljstvu, pri čemu majke provode manje sati na poslu i izvještavaju o pozitivnijem roditeljskom ponašanju. Kako bismo odredili veličinu ovih učinaka spola, izračunali smo Cohenov d. Za duljinu radnoga vremena Cohenov $d$ je 0,35 , a za pozitivno roditeljstvo 0,59, što znači da se radi o umjerenim efektima.

Preliminarnim analizama također smo ispitali doživljavaju li očevi i majke veće ometanje radne uloge roditeljskom ili roditeljske radnom te koja im je uloga važnija (t-test za zavisne uzorke). Pokazalo se da i očevi $(\mathrm{t}(161)=14,61, \mathrm{p}<0,001)$ i majke $(\mathrm{t}(379)=16,46, \mathrm{p}<0,001)$ izvještavaju o većem ometanju roditeljske uloge radnom nego radne roditeljskom te o većoj važnosti roditeljske nego radne uloge (očevi: $\mathrm{t}(161)=10,17, \mathrm{p}<0,001$; majke: $\mathrm{t}(379)=17,46, \mathrm{p}<0,001)$.

\begin{tabular}{lrrrrrrll}
\hline & \multicolumn{7}{c}{ Očevi $(\mathrm{N}=162)$} & \multicolumn{2}{l}{ Majke $(\mathrm{N}=380)$} & & & \\
& $\mathrm{M}$ & $\mathrm{SD}$ & $\mathrm{M}$ & $\mathrm{SD}$ & $\mathrm{t}$ & $\mathrm{df}$ & $\mathrm{p}$ \\
\hline \multirow{2}{*}{ Tjedno radno vrijeme u satima } & 46,08 & 7,21 & 43,23 & 8,44 & 3,75 & 539 & $0,000^{* * *}$ \\
Autonomija na poslu & 2,94 & 0,77 & 2,77 & 0,69 & 2,55 & 540 & 0,011 \\
Zahtjevi posla & 1,91 & 0,47 & 1,84 & 0,58 & $1,53^{\mathrm{a}}$ & 367,72 & 0,126 \\
Fleksibilnost posla & 3,52 & 1,61 & 3,83 & 1,44 & $-2,06^{\mathrm{a}}$ & 276,26 & 0,040 \\
Važnost roditeljske uloge & 9,60 & 0,92 & 9,78 & 0,83 & $-2,16^{\mathrm{a}}$ & 278,32 & 0,032 \\
Važnost poslovne uloge & 7,87 & 2,19 & 8,03 & 1,93 & $-0,87$ & 540 & 0,386 \\
Ometanje radne uloge roditeljskom & 1,80 & 0,53 & 1,89 & 0,59 & $-1,59$ & 540 & 0,113 \\
Ometanje roditeljske uloge radnom & 2,54 & 0,66 & 2,41 & 0,64 & 2,17 & 540 & 0,030 \\
Pozitivno roditeljstvo & 3,40 & 0,35 & 3,59 & 0,31 & $-5,81$ a & 271,12 & $0,000^{* * *}$ \\
Negativno roditeljstvo & 2,28 & 0,47 & 2,33 & 0,50 & $-1,08$ & 540 & 0,280 \\
Popustljivost & 2,41 & 0,60 & 2,39 & 0,62 & 0,47 & 540 & 0,641 \\
& & & & & & &
\end{tabular}

Napomena: akorekcija zbog nehomogene varijance (statistički značajnoga Leveneova testa) *** $\mathrm{p}<0,005$ (Bonferronijeva korekcija)

\section{Prediktori roditeljskoga ponašanja zaposlenih roditelja}

Kako bismo odgovorili na glavna istraživačka pitanja, za sva$\mathrm{ku}$ od tri mjere roditeljskoga ponašanja proveli smo hijerarhijske regresijske analize (HRA), u kojima smo, u skladu s modelom odrednica roditeljskoga ponašanja (Belsky, 1984.), 13 razmatranih prediktora uvodili u regresijske jednadžbe u 4 bloka. Prvi blok činile su karakteristike roditelja (dob, broj djece i stupanj obrazovanja), drugi objektivna obilježja posla (radno vrijeme, autonomija, zahtjevi i fleksibilnost), treći subjektivni doživljaj posla (procjene sukoba i važnosti uloga), a četvrti karakteristike djeteta (dob i spol). Korelacije između prediktorskih i kriterijskih varijabli prikazane su u Tablici 3, a rezultati HRA u Tablicama 4 (očevi) i 5 (majke). 
DRUŠ. ISTRAŽ. ZAGREB GOD. 20 (2011),

BR. 3 (113),

STR. 647-669

SOČO, M., KERESTEŠ, G. RODITELJSKO..

2 TABLICA 3

Korelacije prediktor-

skih i kriterijskih

varijabli primijenjenih

u regresilskim

analizama u uzorku

očeva (iznad glavne

dijagonale) i majki

(ispod glavne

dijagonale)

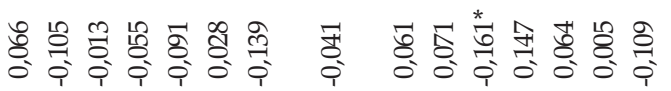

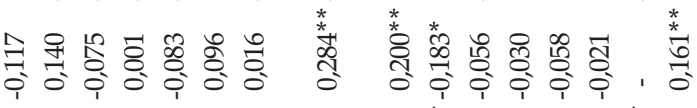

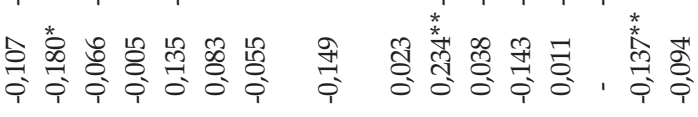

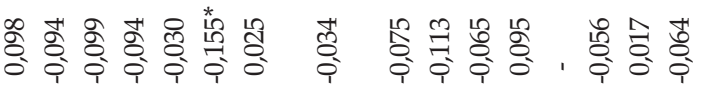

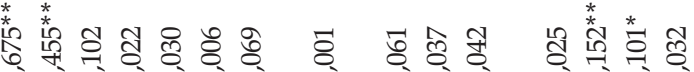

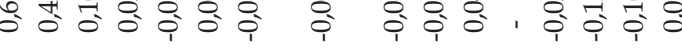

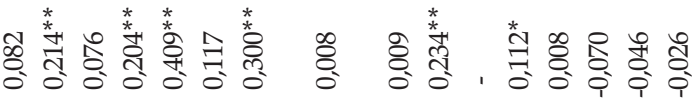

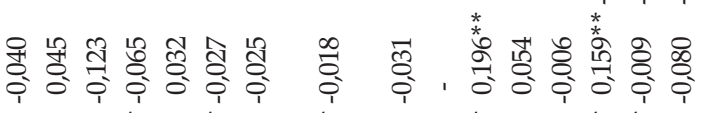

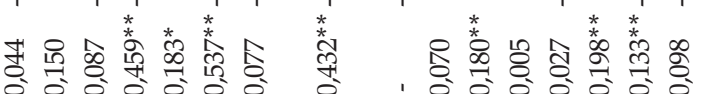

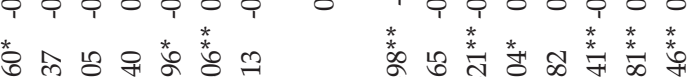

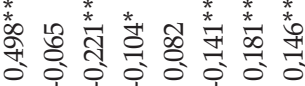

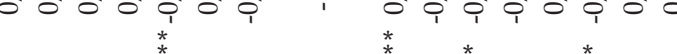

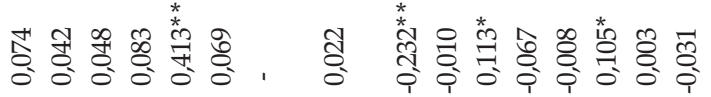

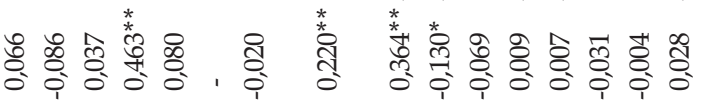

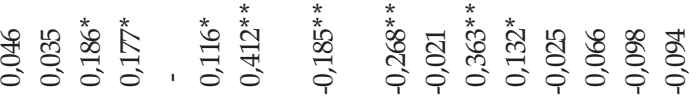

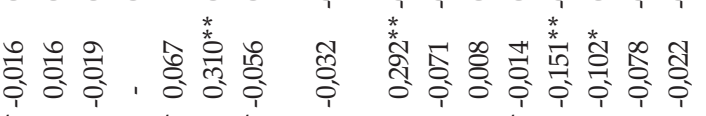

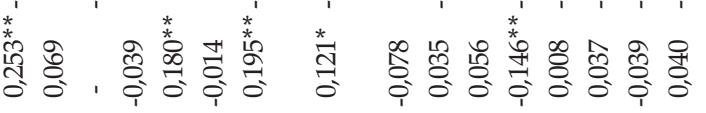

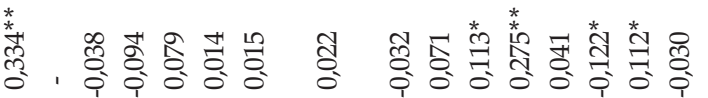

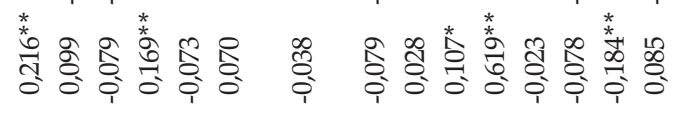

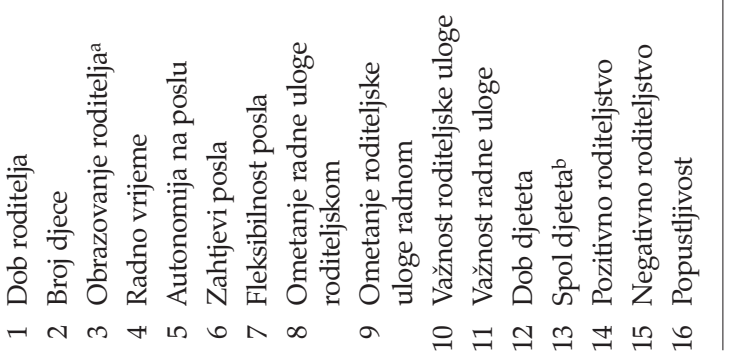

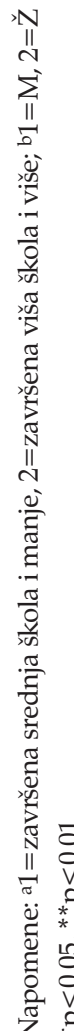




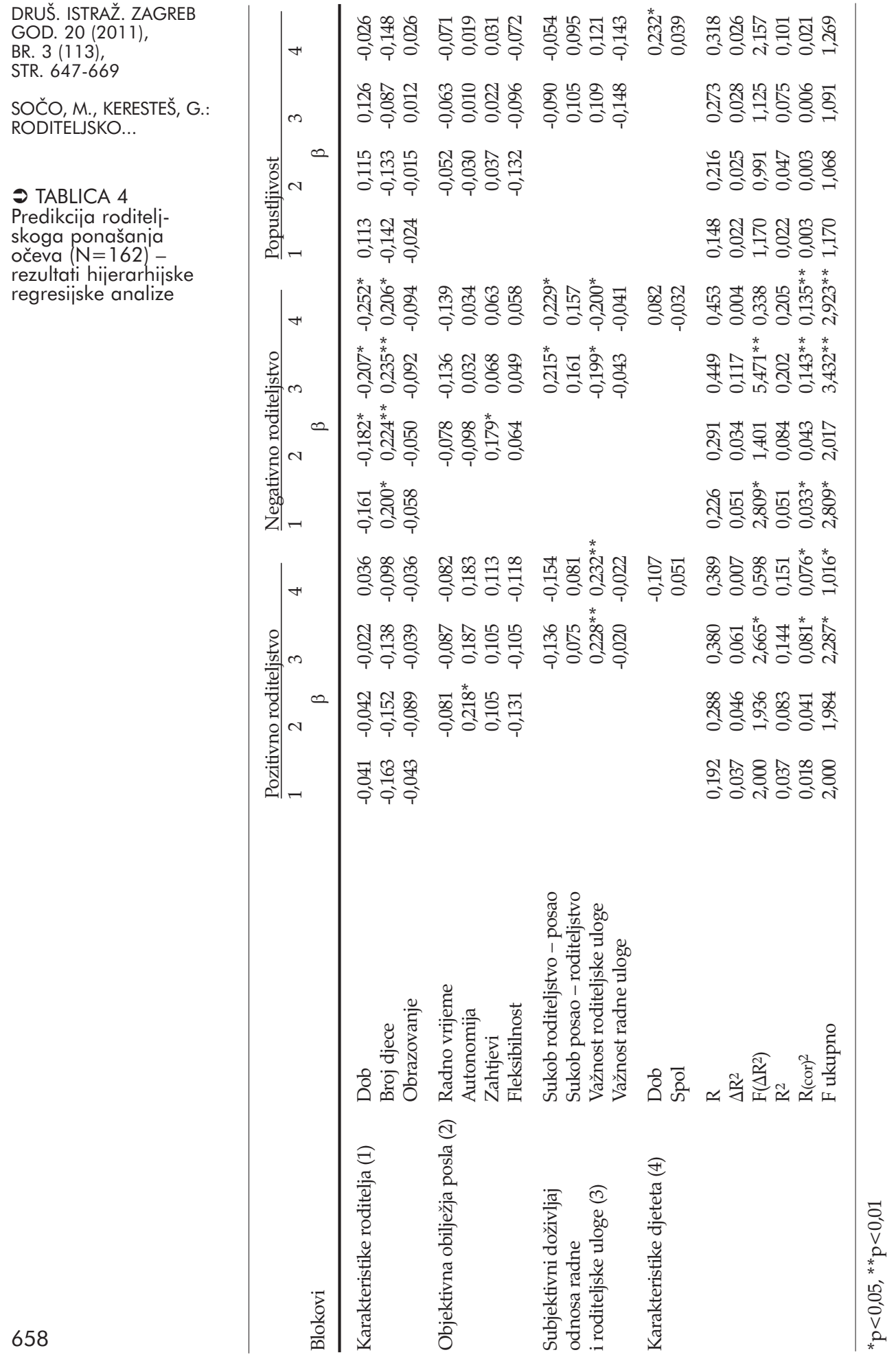




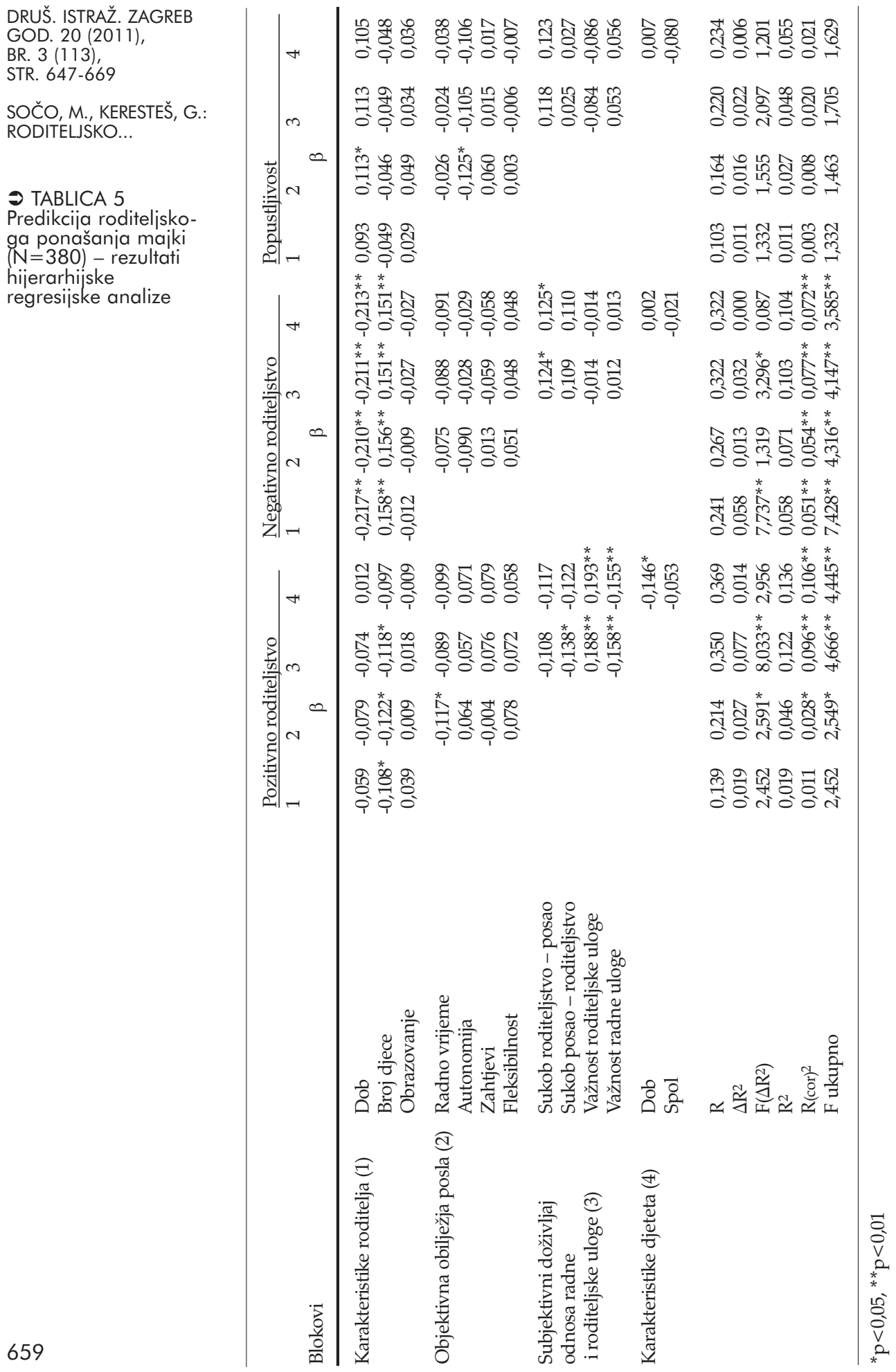




\section{Prediktori pozitivnoga roditeljstva}

Karakteristike očeva nisu objasnile značajan postotak varijance njihova pozitivnog roditeljstva. Uvođenje objektivnih obilježja posla nije pridonijelo boljoj predikciji, no kao značajan prediktor izdvojila se autonomija - očevi s većom autonomijom izvijestili su o pozitivnijem roditeljstvu. Tek je uvođenjem subjektivnoga doživljaja posla objašnjen značajan postotak varijance očeva pozitivnog roditeljstva. Kao značajan prediktor izdvojila se važnost roditeljske uloge - očevi kojima je roditeljska uloga važnija pokazuju više pozitivnoga roditeljstva. Karakteristike djeteta nisu značajno povećale postotak objašnjene varijance. Ukupno su prediktorske varijable objasnile $7,6 \%$ (korigirane) varijance pozitivnoga roditeljstva očeva, a jedini značajan prediktor $\mathrm{u}$ zadnjem koraku ostala je važnost roditeljske uloge.

Karakteristike majki nisu objasnile značajan postotak varijance njihova pozitivnog roditeljstva, ali se broj djece izdvojio kao značajan prediktor - majke s manje djece pokazuju više pozitivnoga roditeljstva. Objektivne karakteristike posla povećale su postotak objašnjene varijance za $2,7 \%$, a značajan je prediktor radno vrijeme - majke s kraćim radnim vremenom pokazuju više pozitivnoga roditeljstva. Varijable subjektivnoga doživljaja posla objasnile su dodatnih $7,7 \%$ varijance. Značajni prediktori jesu sukob radne uloge s roditeljskom ulogom te važnost obaju uloga. Majke kojima je roditeljska uloga važnija, a poslovna manje važna te one kojima posao manje ometa roditeljstvo, pokazuju više pozitivnoga roditeljstva. Karakteristike djeteta nisu značajno povećale postotak objašnjene varijance, ali se dob djeteta pokazala značajnim prediktorom. Više pozitivnoga roditeljstva pokazuju majke mlađe djece. Ukupno je objašnjeno 10,6\% (korigirane) varijance majčina pozitivnog roditeljstva, a značajni prediktori $u$ zadnjem koraku bili su, uz dob djeteta, važnost obiju uloga.

\section{Prediktori negativnoga roditeljstva}

Karakteristike očeva objasnile su 3,3\% (korigirane) varijance njihova negativnog roditeljstva. Jedini značajan prediktor iz ovoga bloka jest broj djece - očevi s većim brojem djece skloniji su negativnom roditeljstvu. Objektivna obilježja posla nisu objasnila značajan dodatni postotak varijance, ali su zahtjevi posla bili samostalni značajni prediktor - očevi sa zahtjevnijim poslom skloniji su negativnom roditeljstvu. U ovom koraku broj djece ostao je značajan prediktor, a dob očeva također je postala statistički značajna, uz veću sklonost negativnom roditeljstvu mlađih očeva. Subjektivni doživljaj posla objašnjava dodatnih $11,7 \%$ varijance, a kao značajni prediktori izdvajaju se sukob roditeljske uloge s radnom ulogom i važnost roditeljske uloge. Očevi kojima roditeljska uloga više 
DRUŠ. ISTRAŽ. ZAGREB GOD. 20 (2011), BR. 3 (113)

STR. 647-669

SOČO, M., KERESTEŠ, G.: RODITELJSKO... ometa radnu i kojima je roditeljska uloga manje važna pokazuju više negativnoga roditeljstva. S uvođenjem karakteristika djeteta nije došlo do značajne promjene u postotku objašnjene varijance. Ukupno su prediktorske varijable objasnile $13,5 \%$ (korigirane) varijance negativnoga roditeljstva očeva, a značajni prediktori u zadnjem koraku bili su dob roditelja, broj djece, sukob roditeljske s radnom ulogom i važnost roditeljske uloge.

Karakteristike majki objasnile su 5,1\% (korigirane) varijance njezina negativnog roditeljstva. Kao značajni prediktori izdvojili su se majčina dob i broj djece. Mlađe majke i one s više djece sklonije su negativnom roditeljstvu. Objektivna obilježja posla nisu pridonijela boljem objašnjenju varijance, dok su majčini subjektivni doživljaji posla povećali postotak objašnjene varijance za značajnih $3,2 \%$, uz sukob roditeljske uloge s radnom ulogom kao značajan samostalni prediktor. Majke kojima roditeljska uloga više ometa radnu sklonije su negativnom roditeljstvu. Karakteristike djeteta nisu značajno povećale proporciju objašnjene varijance. Ukupno su prediktorske varijable objasnile 7,2\% (korigirane) varijance negativnoga roditeljstva majki. Značajni prediktori u posljednjem koraku bili su majčina dob, broj djece i sukob roditeljske s radnom ulogom.

\section{Prediktori popustljivosti}

Ni u uzorku očeva ni u uzorku majki obuhvaćeni prediktori nisu objasnili statistički značajan postotak varijance roditeljske popustljivosti. U uzorku očeva dob djeteta pokazala se značajnim samostalnim prediktorom $\mathrm{u}$ posljednjem koraku analize - očevi su popustljiviji prema starijoj djeci. U uzorku majki dob roditelja pokazala se značajnim samostalnim prediktorom $u$ drugom i trećem, a autonomija u poslu u trećem koraku analize, pri čemu su se starije majke i one s manjom autonomijom u poslu pokazale popustljivijima.

\section{RASPRAVA}

Za razliku od stvarnoga života zaposlenih roditelja, u kojem su posao i roditeljstvo neodvojivo isprepleteni, u znanosti se ta dva područja života uglavnom proučavaju odvojeno. Istraživanja roditeljskoga ponašanja provode se unutar razvojne psihologije, a istraživanja posla unutar psihologije rada. Ovaj rad temelji se na integraciji tih dvaju područja istraživanja, odnosno, specifičnije, na integraciji istraživanja determinanti roditeljskoga ponašanja s istraživanjima interakcija posao - obitelj, s ciljem utvrđivanja obilježja radnoga konteksta povezanih $\mathrm{s}$ roditeljskim ponašanjem zaposlenih roditelja.

Prvo pitanje na koje smo željeli odgovoriti bilo je koliki dio varijance roditeljskoga ponašanja objašnjavaju obuhvaćeni objektivni i subjektivni aspekti radnoga konteksta te je li 
DRUŠ. ISTRAŽ. ZAGREB GOD. 20 (2011) BR. $3(113)$

STR. 647-669

SOČO, M., KERESTEŠ, G.: RODITELJSKO.. posao važnija determinanta majčina ili očeva roditeljstva. Izabranim skupom prediktora objašnjeno je 7,6\% varijance očeva pozitivnog roditeljstva, $13,5 \%$ varijance očeva negativnog roditeljstva, $10,6 \%$ varijance majčina pozitivnog roditeljstva i $7,2 \%$ varijance majčina negativnog roditeljstva. Individualne razlike $\mathrm{u}$ roditeljskoj popustljivosti nismo uspjeli objasniti obuhvaćenim prediktorima. Rezultati su jasno pokazali da je roditeljsko ponašanje povezanije sa subjektivnim doživljajem posla nego s objektivnim obilježjima posla. Nakon kontrole karakteristika roditelja, objektivna obilježja posla objasnila su $4,6 \%$ očeva i $2,7 \%$ majčina pozitivnog roditeljstva te $3,4 \%$ očeva i 1,3\% majčina negativnog roditeljstva. Nakon kontrole karakteristika roditelja i objektivnih obilježja posla, subjektivni doživljaj posla objasnio je $6,1 \%$ očeva i $7,7 \%$ majčina pozitivnog roditeljstva te $11,7 \%$ očeva i $3,2 \%$ majčina negativnog roditeljstva. Iz proporcija objašnjene varijance vidi se da su objektivna obilježja posla nešto povezanija s očevim roditeljskim ponašanjem nego s majčinim. Subjektivna obilježja posla također su povezanija s očevim nego s majčinim negativnim roditeljstvom, dok je za pozitivno roditeljstvo povezanost nešto veća kod majki nego kod očeva.

Drugo istraživačko pitanje bilo je utvrditi koji su od ispitivanih objektivnih i subjektivnih aspekata radnoga konteksta najviše povezani s roditeljskim ponašanjem te jesu li povezanosti slične za očeve i za majke. Rezultati su pokazali da nema značajnijih spolnih razlika u povezanostima karakteristika posla i roditeljskoga ponašanja, jer je smjer povezanosti prediktora i kriterija u oba uzorka jednak, a veličine povezanosti slične. Subjektivni aspekti posla pokazali su se medijatorima povezanosti između objektivnih obilježja i roditeljskoga ponašanja. Malobrojni značajni regresijski koeficijenti objektivnih obilježja - povezanost duljega radnog vremena majki s manje pozitivnoga roditeljstva, veće autonomije očeva posla s više pozitivnoga roditeljstva, veće autonomije majčina posla s manjom popustljivošću i veće zahtjevnosti očeva posla s više negativnoga roditeljstva - postali su neznačajni uvođenjem varijabli subjektivnoga doživljaja posla i odnosa posao - roditeljstvo. Najvažnijim prediktorima roditeljskoga ponašanja obaju roditelja pokazali su se doživljaj ometanja radne uloge roditeljskom i procjena važnosti roditeljske uloge. Kod majki je i važnost radne uloge značajan prediktor.

Očevi i majke koji procjenjuju da im roditeljska uloga više ometa radnu skloniji su negativnom roditeljstvu od roditelja koji osjećaju manji sukob na liniji roditeljstvo - posao. Ovaj je nalaz vrlo zanimljiv i donekle neočekivan, jer su ranija istraživanja i teorijska razmatranja sugerirala kako je za obiteljsko funkcioniranje važniji drugi smjer sukoba posla i obitelji - ometanje obiteljskih uloga poslovnom (Gronlund, 2007.; Mal- 
DRUŠ. ISTRAŽ. ZAGREB GOD. 20 (2011), BR. 3 (113)

STR. $647-669$

SOČO, M., KERESTEŠ, G.: RODITELJSKO... lard i Lance, 1998.; Stewart i Barling, 1996.). No naši rezultati pokazuju kako je ometanje radne uloge roditeljskom prediktivnije za roditeljsko negativno ponašanje od ometanja roditeljske uloge radnom, unatoč tomu što je i u majki i u očeva sukob posao - roditeljstvo veći nego sukob roditeljstvo - posao. Pri razmatranju ovoga nalaza treba uzeti u obzir karakteristike našeg uzorka. Kako je riječ o visokoobrazovanim roditeljima iznadprosječnih primanja, od kojih znatan dio obavlja složene, rukovodeće poslove, zahtjevi roditeljstva te percepcija ometanja poslovne uloge roditeljskom, iako $\mathrm{u}$ apsolutnim vrijednostima nisu visoki, mogu izazvati napetost i negativno raspoloženje, koji se mogu očitovati u sklonosti negativnom roditeljstvu. Ovakvo tumačenje podupiru rezultati Stewartove i Barlinga (1996.), koji su pokazali da dio povezanosti između iskustava na poslu i roditeljskoga ponašanja očeva objašnjava negativno raspoloženje i afekt. Veća povezanost negativnoga roditeljstva s doživljajem ometanja radne uloge roditeljskom nego roditeljske radnom može također biti posljedica roditeljskih očekivanja. U javnosti je raširenije uvjerenje da posao ometa roditeljsko funkcioniranje nego obrnuto, zbog čega roditelji mogu u većoj mjeri očekivati tu vrstu konflikta te biti pripremljeniji i otporniji na nju. Manja pripremljenost za mogućnost ometanja poslovne uloge roditeljskom može rezultirati većim utjecajem te vrste sukoba na negativno roditeljsko ponašanje. Treba također spomenuti kako je doživljaj ometanja roditeljske uloge radnom na očekivan način povezan $\mathrm{s}$ roditeljskim ponašanjima i $\mathrm{u}$ jednakom smjeru kao i ometanje radne uloge roditeljskom, samo što te povezanosti u zadnjem koraku HRA nisu dosegnule statističku značajnost.

Očevi i majke kojima je roditeljska uloga važnija pokazuju više pozitivnoga roditeljstva, a očevi i manje negativnoga roditeljstva. U majki je sklonost pozitivnom roditeljstvu povezana i s manjom važnosti radne uloge. Ovi nalazi u skladu su s teorijama socijalnih uloga (Reitzes i Mutran, 2002.) i pokazuju kako su veća važnost, vrijednost i značenje određene uloge povezani s pozitivnijim i učinkovitijim ponašanjima u toj ulozi.

Neznačajna povezanost zahtjeva posla i roditeljskoga ponašanja u skladu je s nalazom Stewartove i Barlinga (1996.), ali u suprotnosti s nalazima drugih autora (Crouter i sur., 2001.; Repetti i Wood, 1997.). U suprotnosti s većinom ranijih nalaza (Crouter i sur., 1999., 2001.; Mason i sur., 1994.; Menaghan i Parcel, 1991.; Muller, 1995.) jesu i neznačajne povezanosti roditeljskoga ponašanja s autonomijom u poslu i duljinom radnoga vremena. Whitbeck i suradnici (1997.) dobili su nalaz sukladan našem (odsutnost povezanosti autonomije i roditeljstva) za majke, ali je u uzorku očeva autonomija u poslu bila povezana s pozitivnijim roditeljskim ponašanjima. Odsut- 
DRUŠ. ISTRAŽ. ZAGREB GOD. 20 (2011) BR. $3(113)$

STR. 647-669

SOČO, M., KERESTEŠ, G.: RODITELJSKO.. nost ovih povezanosti dijelom je posljedica pristranosti uzorka, zbog koje je raspon variranja roditeljskoga ponašanja i njegovih pretpostavljenih prediktora smanjen. U uzorcima heterogenijega socioekonomskog statusa može se očekivati veći varijabilitet ispitivanih varijabli i njihove jače povezanosti. Za zahtjeve posla odsutnost povezanosti dijelom može biti posljedica razmjerno niske pouzdanosti te skale. Neznačajne povezanosti upućuju i na moguće moderatore koji u našem radu nisu razmatrani, ali bi ih u budućim istraživanjima trebalo uzeti u obzir. Primjerice, ličnost roditelja u velikoj mjeri određuje i roditeljsko ponašanje (Belsky, 1984.) i doživljaj posla, pa povezanosti posla i roditeljstva mogu biti različite za roditelje koji se razlikuju po osobinama ličnosti.

Karakteristike roditelja i djeteta obuhvaćene našim istraživanjem pokazale su se manje važnim prediktorima roditeljskoga ponašanja od radnoga konteksta, što je u skladu s modelom determinanti roditeljskoga ponašanja. Iako Belsky (1984.) pretpostavlja da na roditeljsko ponašanje najviše utječu karakteristike roditelja, potom kontekst $\mathrm{u}$ kojem se roditeljsko funkcioniranje odvija (koji obuhvaća i roditeljev posao), a najmanje karakteristika djeteta, roditeljske karakteristike kojima pridaje najveću važnost jesu ličnost i psihičko zdravlje, a ne demografska obilježja obuhvaćena našim istraživanjem. U ukupnom skupu prediktora razmatranih $\mathrm{u}$ ovom radu (u zadnjem koraku HRA) s karakteristikama roditelja povezano je samo negativno roditeljstvo - mlađi očevi i majke te oni s većim brojem djece skloniji su negativnom roditeljstvu. Takvi su nalazi poznati iz ranijih istraživanja (vidjeti Holden, 2010.). Od karakteristika djeteta, nakon kontrole karakteristika roditelja i radnoga konteksta, samo je jedna povezanost značajna - očevi su popustljiviji prema starijoj djeci. I ovaj nalaz ima potvrdu u ranijim radovima (Holden, 2010.).

Nalaz o izraženijem ometanju roditeljstva poslom nego posla roditeljstvom u roditelja obaju spolova u skladu je s očekivanjima i rezultatima ranijih istraživanja (Jelušić i Maslić Seršić, 2005.; Mallard i Lance, 1998.; Šverko i sur., 2002.), kao i nalaz o kraćem radnom vremenu (Šverko i sur., 2002.) i više pozitivnoga roditeljstva majki u odnosu na očeve (Kuterovac Jagodić i sur., 2006.). Odsutnost spolnih razlika u doživljaju ometanja roditeljske uloge radnom i radne uloge roditeljskom u skladu je s nalazima Anne Gronlund (2007.), dobivenima na švedskim zaposlenicima, ali u neskladu s većinom ranijih nalaza, prema kojima žene doživljavaju veći sukob posla i obitelji (Wiersma i van den Berg, 1991.), odnosno roditeljstva (Mallard i Lance, 1998.) od muškaraca. Śverko i suradnici (2002.) utvrdili su da spol nije povezan s jačinom konflikta posao - obitelj, ali je konflikt obitelj - posao također bio izraženiji u žena. Važno je istaknuti kako naši rezultati, iako uz Bonferronijevu 
DRUŠ. ISTRAŽ. ZAGREB GOD. 20 (2011), BR. 3 (113),

STR. $647-669$

SOČO, M., KERESTEŠ, G.: RODITELJSKO... korekciju nisu dosegnuli statističku značajnost, pokazuju upravo suprotan trend, odnosno upućuju na veće ometanje roditeljske uloge radnom kod očeva nego kod majki. Proturječnost ovih nalaza upućuje na važnost daljeg ispitivanja spolnih razlika u doživljaju sukoba posla i roditeljstva.

Nekoliko slabosti našeg istraživanja ograničuje njegove nalaze. Najveća je slabost velika pristranost uzorka. Dobiveni rezultati govore o povezanosti posla i roditeljskoga ponašanja roditelja visokoga socioekonomskog statusa - moguće je da posao ima drugačije učinke na roditeljsko ponašanje roditelja nižega SES-a. Kako su svi podaci prikupljeni samoprocjenama, dio dobivenih povezanosti može se pripisati varijanci metode. U budućim je istraživanjima poželjno primijeniti i objektivne mjere roditeljskoga ponašanja ili procjene djeteta. Naposljetku, korelacijska priroda istraživanja onemogućuje uzročno-posljedično tumačenje rezultata.

Unatoč ovim slabostima, prikazano istraživanje ima neke jake strane - sudjelovanje roditelja obaju spolova omogućilo je ispitivanje uloge spola, a primjena specifične mjere sukoba roditeljstva i posla precizniji uvid u odnos posao - roditeljstvo nego što su omogućila ranija istraživanja. Stoga rezultati provedenog istraživanja pridonose boljem razumijevanju roditeljskoga ponašanja zaposlenih roditelja i karakteristika radnoga konteksta povezanih s tim ponašanjem. $S$ teorijskog aspekta, naši rezultati potvrđuju pretpostavku o radnom kontekstu kao važnoj determinanti roditeljskoga ponašanja (Belsky, 1984.) i pokazuju kako je subjektivni doživljaj posla pritom važniji od objektivnih obilježja. S praktične strane, dobiveni nalazi upućuju na aspekte posla i odnosa posao - roditeljstvo povezane s negativnim i pozitivnim roditeljskim ponašanjima, koji bi poslodavcima mogli poslužiti kao smjernice za oblikovanje radnoga konteksta povoljnog za privatni život i roditeljsku ulogu zaposlenika. U tom svjetlu najvažniji je nalaz našeg istraživanja povezanost negativnoga roditeljstva s doživljajem ometanja radne uloge roditeljskom i odsutnost spolnih razlika u toj povezanosti. U budućim istraživanjima trebalo bi ispitati činitelje koji pridonose tom doživljaju, utjecaj kojega bi u stvarnom životu valjalo smanjiti.

\section{LITERATURA}

Belsky, J. (1984.), The Determinants of Parenting: A Process Model. Child Development, 55 (1): 83-96. doi:10.2307/1129836

Costigan, C. L., Cox, M. J. i Cauce, A. M. (2003.), Work-Parenting Linkages Among Dual-Earner Couples at the Transition to Parenthood. Journal of Family Psychology, 17 (3): 397-408. doi:10.1037/0893-3200.17.3.397

Crouter, A. C., Bumpus, M. F., Head, M. R. i McHale, S. M. (2001.), Implications of Overwork and Overload for the Quality of Men's Family Relationships. Journal of Marriage and Family, 63 (2): 404-416. doi:10.1111/j.1741-3737.2001.00404.x 
DRUŠ. ISTRAŽ. ZAGREB GOD. 20 (2011), BR. $3(113)$

STR. 647-669

SOČO, M., KERESTEŠ, G.: RODITELJSKO..
Crouter, A. C., Bumpus, M. F., Maguire, M. C. i McHale, S. M. (1999.), Linking Parents' Work Pressure and Adolescents' Well-Being: Insights into Dynamics in Dual-Earner Families. Developmental Psychology, 35 (6): 1453-1461. doi:10.1037//0012-1649.35.6.1453

Čudina-Obradović, M. i Obradović, J. (2000.), Obitelj i zaposlenost izvan kuće: međusobno ometanje i/ili pomaganje. Revija za socijalnu politiku, 7 (2): 131-145.

Čudina-Obradović, M. i Obradović, J. (2001.), Sukob obiteljskih i radnih uloga: uzroci, posljedice i neriješeni istraživački problemi. Društvena istraživanja, 10 (4-5): 791-819.

Eisenberg, N., Zhou, O., Spinrad, T. L., Valiente, C., Fabes, R. A. i Liew, J. (2005.), Relations Among Positive Parenting, Children's Effortful Control, and Externalizing Problems: A Three-Wave Longitudinal Study. Child Development, 76 (5): 1055-1071. doi:10.1111/j.1467-8624.2005. 00897.x

Gamst, G., Meyers, L. S. i Guarino, A. J. (2008.), Analysis of Variance Designs: A Conceptual and Computational Approach with SPSS and SAS, New York, Cambridge University Press.

Gottfried, A. E., Gottfried, A. W. i Bathurst, K. (2002.), Maternal and Dual-Earner Employment Status and Parenting. U: M. H. Bornstein (ur.), Handbook of Parenting: Volume 2-Biology and Ecology of Parenting (str. 207-229), Hillsdale, Lawrence Erlbaum Associates.

Gronlund, A. (2007.), More Control, Less Conflict? Job Demand-Control, Gender and Work-Family Conflict. Gender, Work \& Organization, 14 (5): 476-497. doi:10.1111/j.1468-0432.2007.00361.x

Holden, G. W. (2010.), Parenting: A Dynamic Perspective, Los Angeles, SAGE.

Hughes, E. L. i Parkes, K. R. (2007.), Work Hours and Well-Being: The Roles of Work-Time Control and Work-Family Interference. Work $\mathcal{E}$ Stress, 21 (3): 264-278. doi:10.1080/02678370701667242

Jelušić, J. i Maslić Seršić, D. (2005.), Obiteljske i radne okolnosti kao prediktori ravnoteže obiteljskog i poslovnog života zaposlenih majki. Suvremena psihologija, 8 (1): 23-36.

Keresteš, G. (2006.), Children's Aggressive and Prosocial Behavior in Relation to War Exposure: Testing the Role of Perceived Parenting and Child's Gender. International Journal of Behavioral Development, 30 (3): 227-239. doi:10.1177/0165025406066756

Keresteš, G., Brković, I. i Kuterovac Jagodić, G. (2008.), Upitnik roditeljskog ponašanja URP-29, Neobjavljen priručnik, Zagreb, Filozofski fakultet.

Kuterovac Jagodić, G., Keresteš, G. i Brković, I. (2006.), Attachment Styles of Parents of Adolescents and Their Parenting Behaviour, 15th Psychology Days in Zadar - Book of Selected Proceedings (str. 167-183), Zadar.

Maccoby, E. E. (2000.), Parenting and Its Effects on Children: On Reading and Misreading Behavior Genetics. Annual Review of Psychology, 51: 1-27. doi:10.1146/annurev.psych.51.1.1

Mallard, A. G. C. i Lance, C. E. (1998.), Development and Evaluation of a Parent-Employee Interrole Conflict Scale. Social Indicators Research, 45 (1-3): 343-370. doi:10.1023/A:1006914418251 
DRUŠ. ISTRAŽ. ZAGREB GOD. 20 (2011), BR. 3 (113),

STR. 647-669

SOČO, M., KERESTEŠ, G.: RODITELJSKO...
Martin, C. A. i Colbert, K. K. (1997.), Parenting: A Life Span Perspective, New York, McGraw-Hill.

Mason, C. A., Cauce, A. M., Gonzales, N., Hiraga, Y. i Grove, K. (1994.), An Ecological Model of Externalizing Behaviors in African-American Adolescents: No Family Is an Island. Journal of Research on Adolescence, 4 (4): 639-655. doi:10.1207/s15327795jra0404_12

McKee, L., Roland, E., Coffelt, N., Olson, A. L., Forehand, R., Massari, C., Jones, D., Gaffney, C. A. i Zens, M. S. (2007.), Harsh Discipline and Child Problem Behaviors: The Roles of Positive Parenting and Gender. Journal of Family Violence, 22 (4): 187-196. doi:10.1007/s10896007-9070-6

Menaghan, E. G. i Parcel, T. L. (1991.), Determining Children's Home Environments: The Impact of Maternal Characteristics and Current Occupational and Family Conditions. Journal of Marriage and the Family, 53 (2): 417-431. doi:10.2307/352909

Muller, C. (1995.), Maternal Employment, Parental Involvement, and Mathematics Achievement Among Adolescents. Journal of Marriage and the Family, 57 (1): 85-100. doi:10.2307/353818

Parke, R. D. (2002.), Fathers and Families. U: M. H. Bronstein (ur.), Handbook of Parenting: Volume 3-Being and Becoming a Parent (str. 27-74), Hillsdale, Lawrence Erlbaum Associates.

Reitzes, D. C. i Mutran, E. J. (2002.), Self-Concept as the Organization of Roles: Importance, Centrality, and Balance. The Sociological Quarterly, 43 (4): 647-667. doi:10.1111/j.1533-8525.2002.tb00070.x

Repetti, R. L. i Wood, J. (1997.), Effects of Daily Stress at Work on Mothers' Interactions with Preschoolers. Journal of Family Psychology, 11 (1): 90-108. doi:10.1037//0893-3200.11.1.90

Russell, G. i Russell, A. (1987.), Mother-Child and Father-Child Relationships in Middle Childhood. Child Development, 58 (6): 1573-1585. doi:10.2307/1130696

Stewart, W. i Barling, J. (1996.), Fathers' Work Experiences Effect Children's Behaviors Via Job-Related Affect and Parenting Behaviors. Journal of Organizational Behavior, 17 (3): 221-232. doi:10.1002/(SICI) 1099-1379(199605)17:3<221::AID-JOB741>3.0.CO;2-G

Šverko, B., Arambašić, L. i Galešić, M. (2002.), Work-Life Balance Among Croatian Employees: Role Time Commitment, Work-Home Interference and Well-Being. Social Science Information, 41 (2): 281-301. doi:10.1177/0539018402041002006

Thompson, C. A. i Prottas, D. J. (2006.), Relationships Among Organizational Family Support, Job Autonomy, Perceived Control, and Employee Well-Being. Journal of Occupational Health Psychology, 11 (1): 100-118. doi:10.1037/1076-8998.10.4.100

Voydanoff, P. (2002.), Linkages between the Work-Family Interference and Work, Family, and Individual Outcomes: An Integrative Model. Journal of Family Issues, 23 (1): 138-164. doi:10.1177/0192513X 02023001007

Whitbeck, L. B., Simons, R. L., Conger, R. D., Wickrama, K. A. S., Ackley, K. A. i Elder, G. H. Jr. (1997.), The Effects of Parents' Working Conditions and Family Economic Hardship on Parenting Behaviors and 
DRUŠ. ISTRAŽ. ZAGREB GOD. 20 (2011)

BR. 3 (113)

STR. 647-669

SOČO, M., KERESTEŠ, G.: RODITELJSKO..
Children's Self-Efficacy. Social Psychology Quarterly, 60 (4): 291-303. doi:10.2307/2787091

Wiersma, U. J. i van den Berg, P. (1991.), Work-Home Role Conflict, Family Climate, and Domestic Responsibilities Among Men and Women in Dual-Earner Families. Journal of Applied Social Psychology, 21 (15): 1207-1217. doi:10.1111/j.1559-1816.1991.tb00466.x

\section{Parenting Behaviors of Employed Parents: Relationships with Objective Job Characteristics and Subjective Experiences of Parenting-Work Interaction}

\author{
Mateja SOČO \\ Kindergarten Ciciban, Velika Gorica \\ Gordana KERESTEŠ \\ Faculty of Humanities and Social Sciences, Zagreb
}

Using Belsky's (1984) model of determinants of parenting as a conceptual framework, this paper examines how parenting behavior of employed parents relates to objective job characteristics (work hours, job demands, job autonomy and job flexibility) and parental subjective experiences of parenting-work interaction (importance of parenting and employee role, and work-to-parenting and parenting-to-work conflict). The study encompasses 162 employed fathers and 380 employed mothers with children aged 3 to 16 years. Data were collected by means of on-line questionnaires applied via Internet. The results show that job characteristics are somewhat more related to paternal than to maternal parenting, especially when negative parenting is concerned. Among both mothers and fathers subjective job experiences are more related to parenting than objective job characteristics. The most important predictors of parenting behavior of both mothers and fathers are parenting-to-work conflict and importance of parenting role. Maternal parenting is also related to importance of employee role. Theoretical as well as practical implications of findings are discussed, and directions for future research are given.

Keywords: mothers, fathers, job, parent-employee interrole conflict, parenting behavior 
DRUŠ. ISTRAŽ. ZAGREB GOD. 20 (2011), BR. $3(113)$

STR. 647-669

SOČO, M., KERESTEŠ, G.: RODITELJSKO...

\section{Elterliches Verhalten berufstätiger Eltern: Bezug zu objektiven Arbeitsmerkmalen und zum subjektiven Erleben des Verhältnisses zwischen den Rollen als Erzieher und im Beruf}

\author{
Mateja SOČO \\ Kindergarten Ciciban, Velika Gorica \\ Gordana KERESTEŠ \\ Philosophische Fakultät, Zagreb
}

Ausgehend vom Modell der Determinanten elterlichen Verhaltens (Belsky, 1984), untersuchen die Verfasserinnen dieser Arbeit das elterliche Verhalten berufstätiger Eltern im Bezug zu objektiven Eigenschaften des jeweils ausgeübten Berufes einerseits (Arbeitszeiten, Anforderungen, Spielraum für autonome und flexible Entscheidungen) und dem subjektiven Erleben des Verhältnisses zwischen den Rollen als Erzieher und im Beruf andererseits (jeweilige Wichtigkeit sowie störende Überschneidungen). An der Untersuchung nahmen 162 berufstätige Väter und 380 berufstätige Mütter teil, die Kinder im Alter von 3 bis 16 Jahren hatten. Die Datenerhebung erfolgte online. Die Untersuchungsergebnisse zeigen, dass die Arbeitsmerkmale in etwas stärkerem Maße mit dem Verhalten der Väter als dem der Mütter in Bezug stehen, zumal wenn es um negatives Elternverhalten geht. Das subjektive Erleben des ausgeübten Berufes ist bei Müttern und Vätern stärker ausgeprägt als das Erleben der objektiven Arbeitsmerkmale an sich. Die bedeutendsten Prädiktoren für das erzieherische Verhalten von Müttern und Vätern sind der Eindruck, dass die Rolle im Beruf durch die Elternrolle beeinträchtigt werde, und die Einschätzung der eigenen Rolle als Erzieher. Des Weiteren steht das Erleben der Rolle als Mutter in einem wesentlichen Zusammenhang mit der Einschätzung der eigenen Bedeutung am Arbeitsplatz. Der Artikel schließt mit einer Erörterung der theoretischen und praktischen Implikationen der gewonnenen Erkenntnisse sowie einem Vorschlag, in welche Richtung zukünftige Forschungen weisen könnten.

Schlüsselbegriffe: Mütter, Väter, Überschneidung der Rollen als Erzieher und im Beruf, elterliches Verhalten 